\title{
The use of new pedagogical practices and modern technologies to increase the competence level of I and II stage students of the specialty " Physical Training" of Polotsk State University
}

\author{
Alena Barun $^{1}$, Natallia Hryshanava ${ }^{1}$, Sviatlana Vashchanka $^{1}$, Natallia Dauhiala ${ }^{2}$, and \\ Sviatlana Andryewskaja ${ }^{2}$ \\ ${ }^{1}$ Department of Physical Training and Sports, Polotsk State University, Novopolotsk, Belarus \\ ${ }^{2}$ Department of Technology and Methods of Teaching, Polotsk State University, Novopolotsk, \\ Belarus
}

\begin{abstract}
The changes taking place in the higher education system in the Republic of Belarus require the search for new pedagogical teaching technologies, the updating of tools, methods and methodological techniques. At Polotsk State University, innovative pedagogical practices and technologies, information and communication technologies and distance learning technologies are widely used in the training of specialists in physical education. When choosing and implementing new pedagogical practices, technologies, forms and methods of teaching, constant requests for the formation of future specialists ' competencies are taken into account. The use of innovative teaching methods increases the quality of students ' knowledge, interest in studying the course and future professional activity.
\end{abstract}

\section{Introduction}

Polotsk State University is the largest regional scientific and educational center with strong traditions and unique scientific and pedagogical schools. Polotsk State University provides training in a number of pedagogical specialties, one of which is "Physical Training". The program is aimed at training highly qualified teaching staff in the field of physical education. Such specialists will be in demand not only as teachers, but also as sports and tourism managers [1]. Students study the theoretical foundations of physical education and sports, physical therapy and massage, physical rehabilitation, methods of teaching winter and summer sports. They also learn to assess the physical abilities of children of different ages, and to organize and conduct classes according to them. Sports training is an integral part of training. For those who are professionally engaged in sports, an individual schedule of studies is drawn up, which allows to combine classes with training for competitions. Graduates of this specialty can continue specialized training in the master's program in the specialty "Physical Education and Sports"[2]. 
The aggravation of competition caused by the growing number of higher education institutions, the constantly increasing requirements of employers to future specialists and the level of their professional competencies determine the relevance of finding and implementing new tools to increase competitiveness in the market of educational services.

In the 21 st century higher education is designed not just to transfer knowledge, but to teach how to transform and question it, to develop the ability of critical thinking [3]. The task of developing key competencies involves not so much a reining of the subject content, but rather a change in the technologies of the educational process [4]. That is why education needs innovative methods and forms of teaching, in which students are not passive listeners, but active participants in the process [5].

The purpose of the study is to substantiate the effectiveness of the use of active teaching methods, innovative practices and technologies in the training of specialists in the field of physical culture and sports at Polotsk State University as well as the use of unique scientific and pedagogical practices and technologies in the educational process that contribute to improving the professional competencies of students of the specialty "Physical Training".

\section{Materials and methods}

Issues of professional training of students with the help of active teaching methods, information and other innovative technologies are presented in the works of foreign and Russian researchers and scientists (John Dewey, William Heard Kilpatrick, DeCorte E., Schrufer G., Vrenger K. , Lindemann I., Ludwig S., De Jager L., V. Yu.Babaytseva, A. A. Verbitsky, V. S. Volodin, A. P. Panfilova, I. V. Ushatov, E. A. Levanova, I. A. Zimnaya, M. M. Bunyaev, L. I. Doliner, E. I. Kuznetsov, N. V. Safronov, as well as Belarusian scientists (A. I. Zhuk, S. N. Zakharova, S. V. Kruchinin, N. S. Kurylenko, G. K. Selevko, etc.) [6-13]. So the researcher A. A. Verbitsky believes that the use of active learning methods in higher education contributes to the formation of students' not only cognitive, but also professional motives and interests; education of the thinking of the expert; the formation of a holistic view about professional activity; the formation of social skills of interaction and communication, individual and joint decision-making; the sense of responsibility towards the business [14].

Currently, due to the introduction of new areas of professional activity in the field of physical education and sports, there is a need for analytical studies concerning the features of the use of active teaching methods in the pedagogy of physical education and sports [15]. The effectiveness of the use of active teaching methods in the system of personnel training in the field of physical culture and sports is described and proved in the works of S. D. Neverkovich, E.P. Popova, O. P. Topyshev and others. V. S. Volodina found that the implementation of active teaching methods (the use of training cards, flowcharts and didactic games) in the professional training of future physical education teachers showed high efficiency [16].

The main research methods were the analysis of domestic and foreign scientific and methodological literature, and local documents of the university. To analyse the effectiveness of using information technologies in the educational process and to identify the attitude and degree of readiness of future specialists in physical education to the possibility of working in inclusive education, as well as the presence of formed competencies for the organization of physical education and recreation work in inclusive groups, the questionnaire method was used. 


\section{Results}

The main direction of the Strategic Development Plan of Polotsk State University is to ensure a high quality of educational services, which involves: the use of innovative pedagogical practices and technologies, the redefining of curricula with the introduction of interdisciplinary modules; extensive use of information and communication technologies (formation of electronic educational resources (electronic learning resources, video lectures, virtual laboratories, video films, online simulators, online tests, online tasks for independent work, etc.), the use of distance learning technologies (Google classes, webinars, online consultations, etc.)); encouragement of students to in-depth study of English in parallel with the main specialty; creation of banks of multi-level qualification tasks for all types of control [17].

When choosing and implementing new pedagogical practices, technologies, forms and methods of teaching students of the specialty "Physical Training", constant requests and changes to the formation of the competencies of future specialists are taken into account.

To form professional competencies and personal qualities of future specialists in the field of physical education and sports, active training methods are used. Active teaching methods contribute to the activation of thinking, encourage cognitive and creative activity through the involvement of students in the educational process (see Table 1).

The project method is a procedure for problematizing a task, which is defined as a value in the problem field of the project. Teachers who have used the project method highly appreciate its effectiveness and try to improve the knowledge of its application, associate the project method with pragmatic pedagogy, which proclaimed the slogan "Learning by doing". At the same time, the project method was considered not only as a means of developing creative initiative and independence in learning, but primarily as a tool for establishing a direct connection between the acquired knowledge and skills (exclusively in solving practical problems) [18]. For example, in the discipline "Fundamentals of Management", students of the specialty "Physical Training" implemented the project "Modern managers". The objective was to gain knowledge about successful managers of the world; to gain practical knowledge of information, communication, and educational and cognitive competencies. Together, the students had to choose one of the most successful managers, collect information about him and his activities, record, analyze and organize the material. An important result of this project was:

- Strengthening the ability to independently search, analyze and select the necessary information, work independently and in a group.

- Formation of skills for presenting work results.

- Increase learning motivation.

The wide spread of the Internet and multimedia technologies in many spheres today has influenced the process of studying at universities. Teachers use new technological opportunities to diversify the learning process and increase its efficiency.

In a complex epidemiological situation due to Covid-19, the use of information and communication technologies is the most relevant, since they allow continuous implementation of the educational process. Also, the advantage of using these technologies for students of the specialty "Physical education and sports" is that many active athletes, being on an individual schedule of studies, can combine a continuous training process with their studies. 
Table 1. The use of active teaching methods in the formation of professional competencies of students of the specialty "Physical Education" at Polotsk State University.

\begin{tabular}{|c|c|c|c|}
\hline $\begin{array}{c}\text { Active } \\
\text { teaching } \\
\text { methods }\end{array}$ & $\begin{array}{l}\text { Field of study } \\
\text { (discipline) }\end{array}$ & Purpose & $\begin{array}{c}\text { Result } \\
\begin{array}{c}\text { (The formation of } \\
\text { competencies) }\end{array} \\
\end{array}$ \\
\hline $\begin{array}{l}\text { "Interactive } \\
\text { acquaintance" }\end{array}$ & All disciplines & $\begin{array}{l}\text { Introduction of students and } \\
\text { the teacher, getting to know } \\
\text { each other }\end{array}$ & $\begin{array}{l}\text { The ability to reveal the personal- } \\
\text { individual abilities, } \\
\text { communication skills. }\end{array}$ \\
\hline $\begin{array}{l}\text { "Buzz- } \\
\text { groups" }\end{array}$ & $\begin{array}{l}\text { "Olympic movement } \\
\text { and professional sport, } \\
\text { "Sociology" }\end{array}$ & $\begin{array}{l}\text { Development } \\
\text { communication skills }\end{array}$ & $\begin{array}{l}\text { Ability to overcome uncertainty, } \\
\text { fear of speaking in front of an } \\
\text { audience }\end{array}$ \\
\hline "Info Fair" & $\begin{array}{l}\text { "Pedagogy", } \\
\text { "Psychology of sport" }\end{array}$ & $\begin{array}{l}\text { Finding solutions to } \\
\text { problems in groups }\end{array}$ & $\begin{array}{l}\text { Ability to work in a team to find } \\
\text { joint solutions to problems/tasks; } \\
\text { skills of unconventional thinking }\end{array}$ \\
\hline "Pass the & All disciplines & $\begin{array}{l}\text { Discussion and revision of } \\
\text { the material or solution of the } \\
\text { problem in groups }\end{array}$ & $\begin{array}{l}\text { Ability to solve problems/tasks } \\
\text { creatively and understand the } \\
\text { value of different points of view }\end{array}$ \\
\hline $\begin{array}{l}\text { "Upside } \\
\text { down" }\end{array}$ & $\begin{array}{l}\text { "Business } \\
\text { entrepreneurship", and } \\
\text { "Sport marketing and } \\
\text { management" }\end{array}$ & $\begin{array}{l}\text { Finding a solution to the } \\
\text { main problem by generating } \\
\text { ideas for solving a problem } \\
\text { that is directly opposite to the } \\
\text { original one }\end{array}$ & Soft skills and critical thinking \\
\hline $\begin{array}{l}\text { Mind maps; } \\
\text { logical chains }\end{array}$ & $\begin{array}{l}\text { "Psychology of sport", } \\
\text { "Pedagogy", } \\
\text { "Sociology", } \\
\text { "Theories and methods } \\
\text { of physical education", } \\
\text { «Physical education } \\
\text { for special medical } \\
\text { groups», "Business } \\
\text { and entrepreneurship", }\end{array}$ & $\begin{array}{l}\text { Interpretation of the studied } \\
\text { information in a graphic form } \\
\text { that reflects the semantic, } \\
\text { associative, cause-and-effect } \\
\text { relationships between } \\
\text { concepts and parts of the } \\
\text { subject area }\end{array}$ & $\begin{array}{l}\text { Soft skills when working in } \\
\text { groups; fulfilment of individuality } \\
\text { and creativity, initiative. }\end{array}$ \\
\hline $\begin{array}{l}\text { "Six thinking } \\
\text { hats" }\end{array}$ & $\begin{array}{l}\text { «Theory of sport», } \\
\text { «Marketing of sport } \\
\text { and tourism» }\end{array}$ & $\begin{array}{l}\text { Analysis of the problem from } \\
\text { different points of view, } \\
\text { reasoned presentation of } \\
\text { different positions and search } \\
\text { for the optimal solution }\end{array}$ & $\begin{array}{l}\text { The ability to conduct } \\
\text { communication taking into } \\
\text { account the position of the } \\
\text { interlocutor and organize } \\
\text { cooperation; the ability to manage } \\
\text { attention; the development of } \\
\text { organizational skills, logical } \\
\text { thinking. }\end{array}$ \\
\hline $\begin{array}{l}\text { Flipped } \\
\text { classroom }\end{array}$ & All disciplines & $\begin{array}{l}\text { Solving specific problems, } \\
\text { organizing cooperation, } \\
\text { applying knowledge and } \\
\text { skills in a new situation, } \\
\text { creating a new educational } \\
\text { product by students }\end{array}$ & $\begin{array}{l}\text { Soft skills of independent and } \\
\text { research work }\end{array}$ \\
\hline Jigsaw & All disciplines & $\begin{array}{l}\text { Study and systematization of } \\
\text { a large amount of material }\end{array}$ & $\begin{array}{l}\text { Soft skills through active } \\
\text { interaction in the course of work; } \\
\text { the ability to clearly formulate } \\
\text { thoughts. }\end{array}$ \\
\hline
\end{tabular}

Using the Microsoft Teams and Google Classroom platforms allows to apply the technology of problem-based modular learning (structuring academic disciplines into relatively small independent and completed units of the educational program-modules that are aimed at the formation of certain competencies). Each module reflects learning outcomes, learning content (performance criteria and assessments), methods and forms [19].

In order to analyze the effectiveness of the use of information technologies in the educational process at Polotsk State University on the basis of the Google Forms tool, a feedback questionnaire (form) "Assessment of the students' use of G Suite for education cloud services" was developed. The survey of active users was conducted between April 
and September 2019. The respondents generally evaluate the learning process using G Suite for Education services positively.79\% of respondents rate from 8 to 10 (where 10 is the maximum usability rating) and find it convenient to work in LMS on the basis of G Suite for Education. According to the results obtained, the most useful of the evaluated opportunities for using information technologies were: constant access to educational materials/tasks; participation in online testing; the ability to complete and hand in assignments through an electronic environment; the ability to ask a question to the teacher at any time, hyperlinks to sources, video lectures recorded by teachers. Also, most students agree that the e-course will help them better prepare for the exam /credit in the discipline $(87.7 \%)$. Half of the respondents clearly agree with the need to use e-courses in all disciplines (53.4\%), a third of respondents see the need to use e-courses in all disciplines only as theoretical materials $(32.9 \%)$, and every tenth does not feel the need for this $(11.9 \%)$. One of the students ' complaints is the imperfection of the technical base for the implementation of e-learning. For example, when testing with an open answer, the system cannot always take into account all the correct options, as a result, the student's knowledge is not evaluated objectively. This tendency has been confirmed in other ongoing studies. Making these conclusions, it is impossible not to take into account the subjectivity of students ' assessments, which are related to the conditions of studying a particular discipline and the form of control, due to the individual characteristics of teachers, their vision of the course, their inclination to certain forms of teaching and control [20].

It is worth noting that the main feature of using these technologies is that it is impossible to transfer the entire educational program of the course to the online mode. It should be taken into account that any full-time educational programs will be subjected to changes when switching to the online mode.

In the formation of students' professional competencies of the specialty "Physical Training", the use of practice-oriented training, the forms of which are summer schools and cooperation with the branches of the department, is of great importance. A special place in this direction is occupied by cooperation with the State Educational Institution "Center for Correctional and Developmental Training and Rehabilitation of Novopolotsk" and joint activities for children with disabilities.

Summer school is a kind of pedagogical practice aimed both at gaining new knowledge, sharing experience, and improving existing knowledge, skills and abilities. The Department of Physical Training and Sports of Polotsk State University annually organizes the Summer School of Orienteering. For graduates and undergraduates of the department this is a unique experience of working with people of different ages and with different levels of training (from beginner to master), improving sports skills in organizing training sessions for participants of the summer school (planning and setting distances), experience of volunteer work in arrangement and organizing events, exchange of experience with athletes and coaches from other cities, countries, development of communication skills.

The Summer School of Orienteering has a format of training camps, which offer technical training in the area (distances with a various levels of technical tasks); master classes on technical training from experienced coaches; meetings with the best athletes of the Orienteering Club "Eridan"; a master class on kinesiotaping or myofascial release, general physical training; as well as an entertainment program (for example, a visit to the rope town on the basis of the Department of Tourism and Active Recreation of Polotsk, excursions around Polotsk). Such summer schools can be held in any convenient format for any sport, for different population groups, as well as together with other training courses [21].

To form professional competencies for working with students with special needs of psychophysical development, together with the State Educational Institution "Center for Correctional and Developmental Training and Rehabilitation of Novopolotsk", a series of 
events for children with special needs is held annually, where students gain experience in communicating and working with such students [22]. The need for this practice is related to the fact that general secondary education institutions should become accessible to all categories of children and any teacher, including physical education, should have a number of competencies related to inclusive education.

In 2018, a study was conducted, the purpose of which was to identify the attitude and readiness of future specialists in physical education to the possibility of working in conditions of inclusive education, as well as the presence of formed competencies for organizing physical education and recreation work in inclusive groups. The following results were obtained. More than half of the respondents have a positive attitude to conducting physical activities together with healthy children and children with special needs [23]. About $35 \%$ of students have a negative attitude to inclusive physical education classes. They believe that children with disabilities will feel uncomfortable watching healthy peers perform what they cannot perform.

In addition, this group of respondents is convinced that such classes are very difficult both in terms of organization and methodology. In fact, it can be stated that the theoretical and practical training of future physical education teachers needs to be supplemented, it is not sufficient for the implementation of an inclusive approach.

\section{Conclusion}

At all levels of education, teachers today have the task of educating creative, criticalthinking students who are able to absorb, integrate and apply knowledge at different levels. In teaching practice, there is an ever-growing demand for organizing the teaching of "educational material through engagement, empirical experience and innovative approaches". The use of new teaching methods increases the quality of students ' knowledge, forms an interest in future professional activities. These conclusions are confirmed by the results of the annual survey among graduates of the higher education institution "Learning Outcomes".

Based on the graduates' self-assessment, during their studies at Polotsk State University, they largely formed the competencies necessary for successful work in their chosen specialty. $70 \%$ of graduates are fully satisfied with the training received at the university, $24 \%$ - partially, $4 \%$ found it difficult to answer. Only $1 \%$ is generally dissatisfied. Evaluating the level of general professional training on a 5 -point scale $-27.6 \%$ of graduates gave the highest score, $56.2 \%$ rated it at 4 points, $15.1 \%$ at 3 and $0.8 \%$ of respondents put 2 points. Assessing the level of formation of practical skills and abilities, $52.1 \%$ rated them at 4 points. The highest score was rated by $21.2 \%$ of respondents, $21 \%$ rated -3 points, $5 \%-2$ points and 1 point $-1.7 \%$.

\section{References}

1. PSU is the centre of education and science. https://www.psu.by/universitet/10565-pgutsentr-obrazovaniya-i-nauki

2. Physical Training. https://www.psu.by/obrazovanie/bakalavriat/660-fizicheskajakultura

3. A.A. Shayakhmetova, Innovative methods of teaching higher education teacher. http://repository.enu.kz/handle/123456789/4741

4. G. B. Golub, E. Ya. Kogan, V. A. Prudnikova, Paradigm of current education, Educational Studies, 2, 20-42 (2007) 
5. Unsolvable tasks as the basis of higher education. Interview with A.E. Volkov Educational Studies, 1, 273-277 (2013)

6. E. De Cortee, Innovative perspectives of higher education education and teaching in the 21st century, Educational Studies, 3, 8-29 (2014)

7. L. De Jaegher, What Is the Impact of the Flipping the Classroom Instructional eLearning Model on Teachers, Educational Studies, 2, 175-203 (2020)

8. L. Stephen, Higher Learning: Lessons from an Online Advocate, Educational Studies, 4, 167-187 (2018)

9. G. Schrufer, K. Wrenger, I. Lindemann, "Reflectories" for the Promotion of Competences in Education for Sustainable Development Using the Example of Climate Change, Educational Studies, 2, 152-174 (2020)

10. N. G. Maloshonok, The relationship between the use of the Internet and multimedia technologies in the educational process with student involvement, Educational Studies, 4, 59-83 (2016)

11. M. Karnoy, Ya. I. Kuzminov, Online learning: how it changes the structure of education and the economics of the university. Open discussion, Educational Studies, 3, 8-43 (2015)

12. U. N. Protsenko, Professional training of professionals on physical culture: terminological aspect. http://jurnal.org/articles/2014/ped21.html

13. V. A. Magin, Modernization of the system of professional training of specialists in physical culture and sports based on innovative technologies (2006).

14. I.V. Gordeeva, Active methods of education in the process of preparing a future teacher of physical culture and health for the prevention of illegal behavior of adolescents. http://elib.psu.by:8080/handle/123456789/21566

15. T.V. Levchenkova, Active methods of teaching in pedagogics of physical culture and sports, Science vector of Togliatti State University. Series: Pedagogy, Psychology, 1 (20), 101-104 (2015)

16. V. S. Volodina, Developing the professional readiness of future physical education teachers through active teaching methods, Krasnoyarsk, 2007

17. University Development Strategy. https://www.psu.by/pgu/401-sotrudnikam/12380strategiya-razvitiya-universiteta

18. E. A. Penkovsky, Project method in domestic and foreign pedagogical theory and practice, Education issues, 4, 307-318 (2010)

19. M.A.Vikulina, Yu.A. Popova, Pedagogical technologies in the process of forming the competences of students at the university, Current problems of science and education, 6 (2015)

20. N. Bareika, A.Barun, N. Dauhiala, D. Dauhiala, The role of external stakeholders in ensuring the quality of educational services of Polotsk state university SHS Web Conf 97, (2021) International Conference "Technological Educational Vision" (TEDUVIS 2020)

21. International Summer School on Orienteering at PSU. https://www.psu.by/sobytija/11318-mezhdunarodnaya-letnyaya-shkola-posportivnomu-orientirovaniyu-v-pgu

22. Dear good! https://www.psu.by/sobytija/12426-dorogoyu-dobra-2019

23. E.N. Borun, E.V. Minenok, Readiness of future teachers of physical education to work with children with special features of psychophysical development in conditions of inclusive education, Bulletin of Polotsk State University, S.E, P.S., 15, 148-152 (2018). 